\title{
Chemometric Characterization of Slovenian Red Wines
}

\author{
Milena Ivanović, ${ }^{1}$ Anja Petek, ${ }^{1}$ Maša Islamčević Razboršek ${ }^{1}$ and Mitja Kolar ${ }^{2}$ \\ ${ }^{1}$ University of Maribor, Faculty of Chemistry and Chemical Engineering, Smetanova ulica 17, 2000 Maribor \\ ${ }^{2}$ University of Ljubljana, Faculty of Chemistry and Chemical Engineering, Večna pot 113, 1000 Ljubljana \\ *Corresponding author: E-mail: mitja.kolar@fkkt.uni-lj.si \\ Tel.: (+386)-1-4798-694
}

Received: 31-08-2016

For Cutting Edge 2017

\begin{abstract}
Total phenolic (TPC), flavonoid (TFC) and tannin (TTC) contents, total $\mathrm{SO}_{2}$, total acids, $\mathrm{pH}$, and reducing sugars were measured in twenty five Slovenian red wines from three key wine producing regions, Podravje, Posavje and Primorska. The results were chemometrically analysed and the wines were classified according to wine growing region and vine variety. Principal component analysis proved that TPC, TFC and TTC contents were primarily responsible for variation in the wines. Additionally, linear discriminant analysis (LDA) was performed and resulted in the satisfactory classification of samples by both vine variety and region.
\end{abstract}

Keywords: Slovenian red wines, quality parameters of wine, polyphenols, chemometric analysis.

\section{Introduction}

Slovenia is a small European country with a long history of wine production in three key wine growing regions, Podravje in the east, Primorska in the west and Posavje just south of the center. In Slovenia there are more than 28,000 wineries, producing between 80 and 90 million annually, of which $25 \%$ is red wine. Most of the red wine is produced in Primorska from two well-known vine varieties, Refošk and Merlot.

Wine is a complex matrix and its major components are water (81\%), ethanol (between $11 \%$ and $15 \%$ ) and sugars. Additionally, it contains a wide range of organic and inorganic compounds, including polyphenols, different organic acids and nitrogenous compounds. ${ }^{1}$ The concentration levels of these compounds are influenced by several oenological factors such as origin, vine variety, winemaking practices, ageing and vintage. Their quantitative determination in wines is of considerable importance, since it is known that they are responsible for the wine's taste (polyphenols), colour (anthocyanins), and for beneficial health effects including antioxidant and anti-inflammatory activities. ${ }^{2,3}$ Wine classification is a very important topic in order to detect possible frauds and to establish wine authenticity, which is an important consideration in international markets. ${ }^{4}$ This process consists of building mathematical-statistical models based on quantitative and qualitative information about the natural constituents, such as content of trace elements, ${ }^{5}$ organic wine constituents such as volatile compounds, ${ }^{6}$ sugars, ${ }^{7}$ polyphenols, ${ }^{8}$ anthocyanins, ${ }^{9}$ etc.

Slovenian wine legislation ${ }^{10}$ prescribes that all wines should be submitted to chemical and sensoric-organoleptic analysis before being released to the market. After wines pass the tests, they are assigned a quality level according to the Zaščiteno geografsko poreklo (ZGP), which is similar to the European Union's QWPSR system (Quality Wines Produced in Specified Regions.) Several articles about different analytical techniques, including high-performance liquid chromatography (HPLC), high-performance ion chromatography exclusion (HPICE), inductively coupled plasma emission spectroscopy (ICP-OES), isotope ratio mass spectrometry (IRMS), site-specific natural isotopic fractionation nuclear magnetic resonance (SNIF-NMR) and inductively coupled plasma mass spectrometry 
(ICP-MS) for the determination of different compounds and chemometric classification of Slovenian wines based on these results have been published. ${ }^{11-13}$ In our previous paper, ${ }^{14}$ Slovenian red wines were characterized according to the phenolic acids content, and classified according to vine variety and Slovenian wine growing regions. In the present study, several more variables were taken into account, total polyphenol content (TPC), condensed tannins content (TTC), flavonoids content (TFC), total reducing sugars, total acids content and total $\mathrm{SO}_{2}$ content were determined in twenty-five Slovenian red wines. Additionally, the results obtained were used to build chemometric models for the classification of Slovenian red wines of different vine varieties from the three wine growing regions.

\section{Experimental}

\section{1. Chemicals and Wine Samples}

Rutin, vanillin, gallic acid, Folin-Ciocalteu reagent and $\mathrm{NaOH}$ were supplied by Merck (Germany). $\mathrm{Na}_{2} \mathrm{CO}_{3}$, $\mathrm{I}_{2}$ and $\mathrm{KI}$ were purchased from Sigma-Aldrich (Germany). $\mathrm{AlCl}_{3}$ and $\mathrm{H}_{2} \mathrm{SO}_{4}$ were purchased from Fluka (USA) and methanol (MeOH) from JT Baker (Germany). $\mathrm{CH}_{3} \mathrm{COONa}$ and $\mathrm{HCl}$ were supplied by Carlo Erba (Italy), $\mathrm{CuSO}_{4}$ and $\mathrm{KNaC}_{4} \mathrm{H}_{4} \mathrm{O}_{6}$ were purchased from Kemika (Croatia).

Twenty-five red wines from different Slovenian wineries and different varieties (Table 1) were purchased from local supermarkets. All the wine samples tested originated from four vintages (2011-2015). The wines were stored in a refrigerator at $+4^{\circ} \mathrm{C}$ until analysed.

\section{2. Instrumentation}

Spectrophotometric measurements were carried out using a Cary 100 Varian UV/VIS spectrophotometer (USA). All titration determinations were performed on a Mettler Toledo T50 automatic titration system, using a DGi111-SC glass electrode and DMi140-SC platinum ring electrode. All samples were analysed in triplicate.

\section{3. Analytical Methods}

\section{3. 1. Total Polyphenols Content (TPC)}

Total polyphenol content (TPC) was determined according to the slightly modified standard spectrophotometric method described by Dewanto et al. ${ }^{15}$ The TPC was expressed as grams of gallic acid equivalents per litre ( $g$ $\left.\mathrm{GAE} \mathrm{L}^{-1}\right)$.

\section{3. 2. Total Flavonoids Content (TFC)}

As with TPC, the total flavonoids content (TFC) was measured by UV-VIS spectrophotometer against blank at $415 \mathrm{~nm} .{ }^{15}$ The TFC was expressed as grams of rutin per litre $\left(\mathrm{g} \mathrm{RUT} \mathrm{L}^{-1}\right)$.

\section{3. 3. Total Condensed Tannins Content (TTC)}

Condensed tannins were determined according to the methods described by Sun et al. ${ }^{16}$ The absorbance was measured at $500 \mathrm{~nm}$ against methanol as blank. The TTC was expressed as grams of catechin per litre (g CAT $\left.\mathrm{L}^{-1}\right)$.

\section{3. 4. Chemical Parameters Determined Using an Automatic Titration System}

For all other chemical parameters, a Mettler Toledo T50 automatic titration system was used. Total $\mathrm{SO}_{2}$ was determined according to the M564 method. $5 \mathrm{~mL}$ of $5 \mathrm{M}$ $\mathrm{NaOH}$ were added to $50 \mathrm{~mL}$ of each wine sample, then left to stand for $15 \mathrm{~min}$; after that, $7 \mathrm{~mL}$ of $25 \% \mathrm{H}_{2} \mathrm{SO}_{4}$ and $10 \mathrm{~mL}$ of $10 \% \mathrm{KI}$ were added and the sample was titrated with $\mathrm{I}_{2}$. Total acids content was determined according to the M561 method, where to $10 \mathrm{~mL}$ of the wine sample, $40 \mathrm{~mL}$ of deionised water was added and the sample was titrated with $0.1 \mathrm{M} \mathrm{NaOH}$. For determination of reducing sugars, M566/567 and M568 methods were used, where Fehling solutions (I and II) and titrant solution were prepared initially. To an aliquot of the wine sample (1-3 mL), $5 \mathrm{~mL}$ of Fehling I, $5 \mathrm{~mL}$ of Fehling II solutions and $40 \mathrm{~mL}$ of water were added. The sample

Table 1. Number of samples per wine variety and per wine growing region.

\begin{tabular}{cccc}
\hline Wine growing region & No. of samples & Vine variety & No. of samples \\
\hline Primorska & 13 & Cabernet Sauvignon & 5 \\
& & Merlot & 2 \\
& & Modri Pinot & 1 \\
Podravje & Refošk & 5 \\
& 5 & Cabernet Sauvignon & 1 \\
Posavje & Modri Pinot & 2 \\
& \multirow{2}{*}{ Modra Frankinja } & 2 \\
& & Cabernet Sauvignon & 1 \\
& & Modra Frankinja & 4 \\
\end{tabular}


was boiled for exactly 2 minutes and then cooled to room temperature. Then $10 \mathrm{~mL}$ of $10 \% \mathrm{H}_{2} \mathrm{SO}_{4}$ and $10 \mathrm{~mL} 10 \%$ $\mathrm{KI}$ were added and the mixture was titrated with $0.1 \mathrm{M}$ $\mathrm{Na}_{2} \mathrm{~S}_{2} \mathrm{O}_{3}$. pH was measured according to the M390 method. ${ }^{17}$

\section{4. Statistical Analysis}

Microsoft Excel was used for the data preparation and result outputs. Statistical data treatment was performed using SPSS Statistics (IBM Corp. Released 2013. IBM SPSS Statistics for Windows, Version 22.0. Armonk, NY: IBM Corp.).

\section{Results and Discussion}

The results of all analyses performed on selected Slovenian red wines are listed in the supplementary material (Table 2). The TPC determined by the Folin-Ciocalteu method ranged from 1.24 to $4.01 \mathrm{~g} \mathrm{GAE} \mathrm{L}^{-1}$. These values are in general accordance with results determined for Croatian, Italian, Slovakian, Austrian and Romanian red wines. ${ }^{18-23}$ In the literature, there is relatively little information about TFC in red wines. ${ }^{23,24}$ When our results are compared with the literature data, it is clear that Slovenian red wines are a very rich source of flavonoids; by applying colorimetric method using rutin as a standard, TFC was determined in the range of 0.05 to $0.38 \mathrm{~g}$ RUT $\mathrm{L}^{-1}$. TTC were determined in the concentration range of 0.37-1.92 $\mathrm{g} \mathrm{CAT} \mathrm{L}^{-1}$, where the lowest average TTC was determined in the Modra Frankinja variety. These results are comparable with the literature. ${ }^{25}$ The highest concentration was determined in the Modri Pinot variety from the Primorska wine growing region. For comparison, red wines from Romania can contain $0.63-2.34 \mathrm{~g}$ of tannins $\mathrm{L}^{-1} \cdot{ }^{23}$

Wines can be classified according to sugar content as dry (up to $9 \mathrm{~g} \mathrm{~L}^{-1}$ ), semi-dry (up to $12 \mathrm{~g} \mathrm{~L}^{-1}$ ), semisweet (up to $50 \mathrm{~g} \mathrm{~L}^{-1}$ ) and sweet (above $50 \mathrm{~g} \mathrm{~L}^{-1}$ ) wines. ${ }^{10}$ From these categories we concluded that all of the wines tested belong to the group of dry wines, as they contain from 2 to $8 \mathrm{~g} \mathrm{~L}^{-1}$ of reducing sugars. The total acid content in red wines can be from 3.5 to $10 \mathrm{~g}$ $\mathrm{L}^{-1},{ }^{10}$ and all our results are in this range. According to the literature, ${ }^{10}$ total $\mathrm{SO}_{2}$ must not exceed $160 \mathrm{mg} \mathrm{L}^{-1}$ for a wine with reducing sugars content below $5 \mathrm{~g} \mathrm{~L}^{-1}$, and must not exceed $210 \mathrm{mg} \mathrm{L}^{-1}$ for red wines with reducing sugars content above $5 \mathrm{~g} \mathrm{~L}^{-1}$. Measured $\mathrm{SO}_{2}$ contents were between 5 and $287 \mathrm{mg} \mathrm{L}^{-1}$ for all twenty-five samples. Increased contents of total $\mathrm{SO}_{2}$ were found in just two samples belonging to the Modri Pinot and Modra Frankinja varieties, respectively. $\mathrm{pH}$ values were not significantly different from wine to wine, as they were in the range of 3.37 to 3.98 and are comparable with results reported by other authors. ${ }^{26}$

\section{1. Statistical Analysis}

Exploratory data analysis was performed using the SPSS program. In the first step of the statistical evaluation, the Kolmogorov-Smirnov test (with a significance level of 0.05) was used. According to the results obtained (Table 3), that total $\mathrm{SO}_{2}$ values were not normally distributed, and a logarithmically transformed data form was created in order to achieve correct results in the deviating case. In this way prepared data were used for further analyses. The parametric Pearson correlation test (with significance levels 0.01 and 0.05 ) was used to determine any inter-relation between selected variables (Table 4). Statistically significant positive correlations at the confidence level 0.01 were found between the following parameters: TPC and TFC (0.721), TPC and TTC (0.897), TPC and reducing sugars (0.617) and TTC and reducing sugars (0.580). Positive correlations at the confidence level 0.05 were found between TFC and TTC (0.494) and between TFC and reducing sugars (0.489). Negative correlation at the confidence level of 0.05 was found between $\mathrm{pH}$ and total acids (-0.401): higher acid contents lead to lower $\mathrm{pH}$ values.

For testing the significance of differences between different groups of wine samples (classified according to the Slovenian wine growing regions) box plot analyses were performed. Outliers were detected in data sets of TFC (two samples-one sample from Primorska and another from the Posavje Slovenian wine growing region), $\mathrm{pH}$ (two samples-one sample from Primorska and another from the Podravje wine growing region) and total acids (two samples-Podravje and Posavje).

\section{3. 1. Principal Component Analysis (PCA)}

For the obtained Factor Analysis results, for the creation of a PCA model based on wine growing regions only three statistically important variables were taken into account: TPC, TFC and TTC. Outliers (two samples from the TFC) were discarded from further analysis. To confirm the significance of differences between wine groups regarding the content of the aforementioned statistically important variables, ANOVA tests were performed. According to the results obtained, all of the descriptors were found to be statistically significant at the $\mathrm{p}<0.05$ in the ANOVA outputs. The $\mathrm{p}$ values for TPC, TFC and TTC were $0.03,0.024$ and $2.66 \times 10^{-4}$, respectively. As can be seen in the plot of scores in Figure 1, PC1 is well discriminated between Primorska (group 1) and Podravje (group 2) wines. The wines from the Posavje region (group 3) were positioned in the middle; some samples were dispersed into group 2. The first two PCs explained $96 \%$ of the total variance between wine growing regions of the samples analysed. The highest percentage of phenolic compounds (TPC, TFC and TTC) was found in wine samples from the Primorska region (Figure 1). 


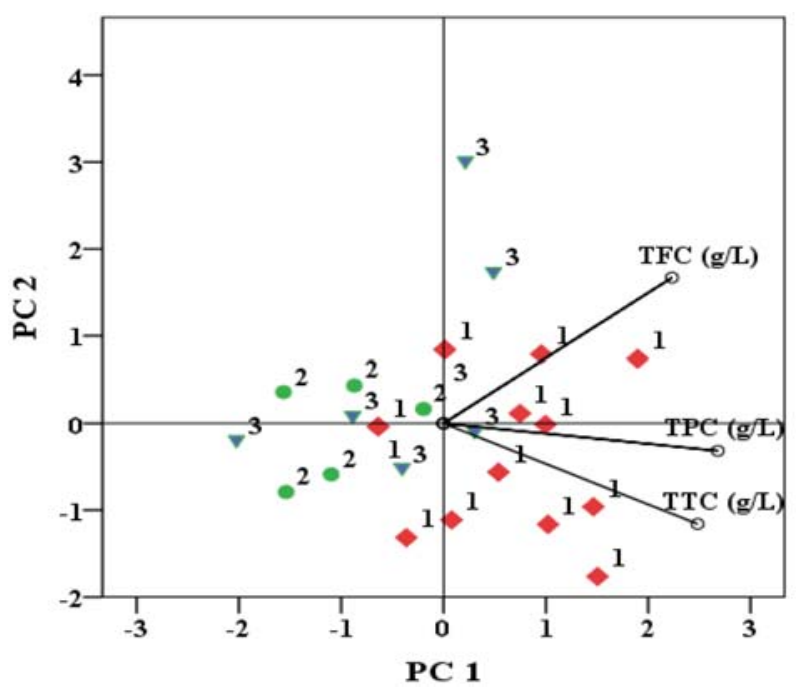

Figure 1. PCA bi-plot in the plane PC2 vs. PC1. The objects are labelled by Slovenian wine growing regions. The first principal component (PC1) explained $78 \%$ of the variation between the samples, and the second (PC2) explained 18\% of the variation. PC1 and PC2 values separate samples according to TPC and TFC, respectively ( $\diamond$ Primorska wine growing region; $\triangle$ Podravje wine growing region and $\square$ Posavje wine growing region)

\section{3. 2. Linear Discriminant Analysis (LDA)}

For LDA classification of the samples from three wine growing regions, TPC and TTC were selected as parameters. The graphic output of classification is shown in Figure 2. The classification rates for the categories mentioned were acceptably good; overall correct classification

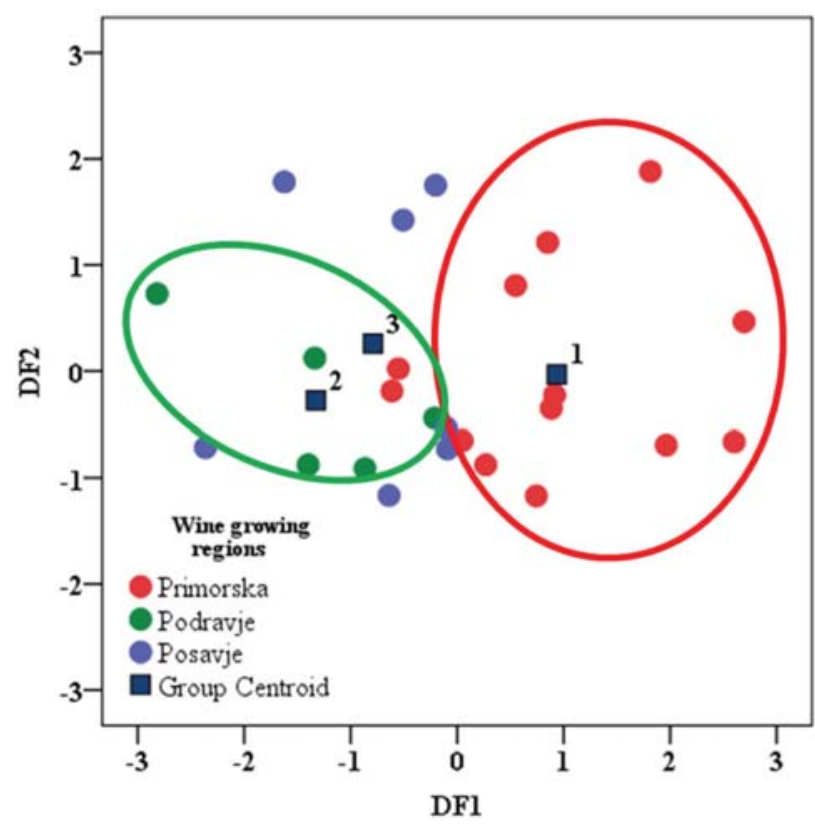

Figure 2. Graphic output of LDA in the plane of the first two discriminant functions. Classification according to Slovenian wine growing regions

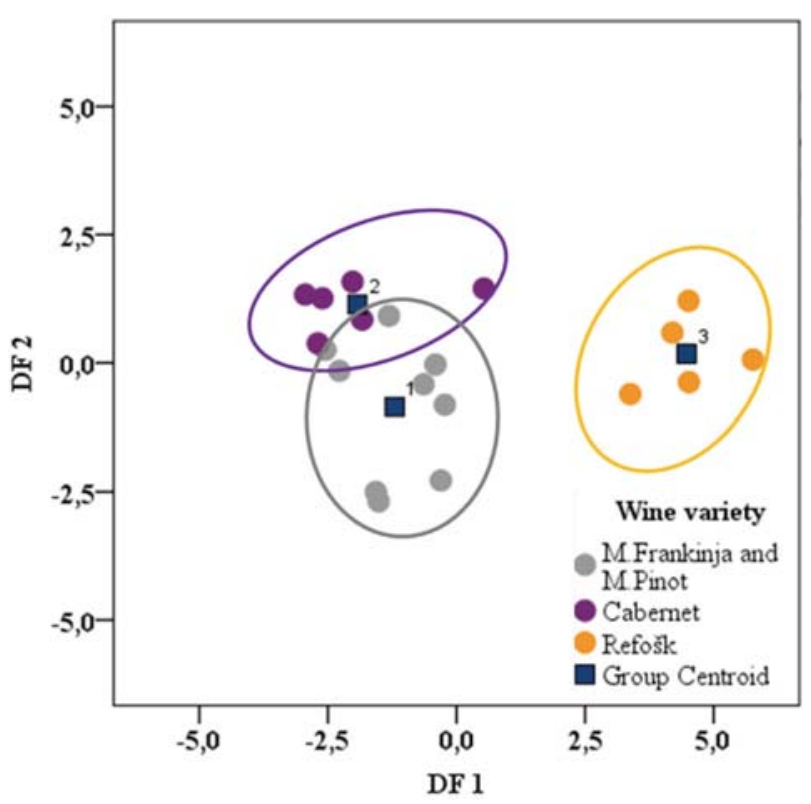

Figure 3. Graphic output of LDA in the plane of the first two discriminant functions. Classification according to varieties.

ratio was $80 \%$ for the training set and almost $70 \%$ for the validation set.

LDA was also used to categorize wine samples for the Cabernet, Refošk, Modra Frankinja and Modri Pinot varieties employing optimally selected variables: TFC, TTC and total acids content; the results are presented in Figure 3. Classification ratio was $90 \%$ for the training set, and $80 \%$ for the validation set. Using the aforementioned descriptors, the Refošk variety is distinguished from the other classes, and formed a group in the positive part of DF 1 . This analysis showed a strong similarity between the Modri Pinot and Modra Frankinja vine varieties, and together they form a group in the negative part of DF 1 . The similarity between these two varieties, according to some other parameters, was also shown. ${ }^{27}$ LDA analysis resulted in classification of samples according to both regions and varieties.

\section{Conclusions}

This paper is one of a few studies on systematic chemical characterization of the most well-known Slovenian red wines. Twenty five wine samples were analysed and 7 selected chemical descriptors (variables) were used for wine characterization. The results show that Slovenian red wines are a very rich source of health beneficial compounds, especially flavonoids. Additionally, the results obtained were chemometrically processed. For this purpose, PCA and LDA were used as the main chemometrical tools. Taking into account TPC, TFC and TTC as the selected descriptors, satisfactory classification of wines was achieved with respect to (a) wine gro- 
wing regions and (b) variety. This study demonstrates the usefulness of variable selection and also suggests the application of a developed model which could be used for wine classification according to several other parameters such as vintage, winemaking practices and alcohol content.

\section{Acknowledgments}

The authors would like to thank dr. Roman Kranvogl for his helpful comments regarding chemometric interpretation.

This work has been supported by the Erasmus Mundus Join-EU-SEE Penta project.

\section{References}

1. S. Moncayo, J. D. Rosales, R. Izquierdo-Hornillos, J. Anzano, J. O. Caceres, Talanta 2016, 158, 185-191. https://doi.org/10.1016/j.talanta.2016.05.059

2. F. Mattivi, C. Zulian, G. Nicolini, L. Valenti, Ann. N. Y. Acad. Sci. 2002, 957, 37-56. https://doi.org/10.1111/j.1749-6632.2002.tb02904.x

3. D. Serrano-Lourido, J. Saurina, S. Hernández-Cassou, A. Checa, Food Chem. 2012, 135, 1425-1431. https://doi.org/10.1016/j.foodchem.2012.06.010

4. R. Garrido-Delgado, L. Arce, A.V. Guamán, A. Pardo, S. Marco, M. Valcárcel, Talanta. 2011, 84, 471-479. https://doi.org/10.1016/j.talanta.2011.01.044

5. I. Geana, A. Iordache, R. Ionete, A. Marinescu, A. Ranca, M. Culea, Food Chem. 2013, 138, 1125-1134. https://doi.org/10.1016/j.foodchem.2012.11.104

6. B. T. Weldegergis, A. de Villiers, A. M. Crouch, Food Chem. 2011, 128, 1100-1109. https://doi.org/10.1016/j.foodchem.2010.09.100

7. A. Caligiani, D. Acquotti, G. Palla, V. Bocchi, Anal. Chim. Acta. 2007, 585, 110-119. https://doi.org/10.1016/j.aca.2006.12.016

8. L. Jaitz, K. Siegl, R. Eder, G. Rak, L. Abranko, G. Koellensperger, S. Hann, Food Chem. 2010, 122, 366-372. https://doi.org/10.1016/j.foodchem.2010.02.053

9. A. de De Villiers, G. Vanhoenacker, P. Majek, P. Sandra, J. Chromatogr. A. 2004, 1054, 195-204. https://doi.org/10.1016/S0021-9673(04)01291-9

10. Zakon o vinu (Slovenian wine laws), Uradni list Republike Slovenije. 2006, https://www.uradni-list.si/1/content?id=75822
11. M. A. Brescia, I. J. Košir, V. Caldarola, J. Kidrič, A. Sacco, J. Agric. Food Chem. 2003, 51, 21-26. https://doi.org/10.1021/jf0206015

12. N. Ogrinc, I. J. Košir, M. Kocjančić, J. Kidrič, J. Agric. Food Chem. 2001, 49, 1432-1440. https://doi.org/10.1021/jf000911s

13. V. S. Šelih, M. Šala, V. Drgan, Food Chem. 2014, 153, 414-423. https://doi.org/10.1016/j.foodchem.2013.12.081

14. M. Ivanović, M. I. Razboršek, M. Kolar, Acta Chim. Slo. 2016, 63, 661-669. https://doi.org/10.17344/acsi.2016.2534

15. X. Dewanto, K. Wu, K. Adom, R. H. Liu, J. Agric. Food Chem. 2002, 50, 3010-3014. https://doi.org/10.1021/jf0115589

16. B. Sun, J. M. Richardo-Da-Silva, I. Spranger, J. Agric. Food Chem. 1998, 46, 4267-4274. https://doi.org/10.1021/jf980366j

17. http://www.mt.com/es/en/home/applications/Application_ Browse_Laboratory_Analytics/Application_fam_browse_ main.html.

18. M. Šeruga, I. Novak, L. Jakobek, Food Chem. 2011, 124, 1208-12016. https://doi.org/10.1016/j.foodchem.2010.07.047

19. V. Katalinić, M. Miloš, D. Modun, I. Musić, M. Boban, Food Chem. 2004, 86, 593-600. https://doi.org/10.1016/j.foodchem.2003.10.007

20. J. Piljac, S. Martinez, T. Stipčević, Z. Petrović, M. MetikošHuković, Am. J. Enol. Vitic. 2004, 55, 417-422.

21. D. Di Majo, M. La Guardia, S. Giammanco, L. La Neve, M. Giammanco, Food Chem. 2008, 111, 45-49. https://doi.org/10.1016/j.foodchem.2008.03.037

22. A. Staško, V. Brezova, M. Mazur, M. Čertik, M. Kalinak, G. Gescheidt, LWT- Food Sci. Technol. 2008, 41, 2126-2135.

23. A. Hosu, V. M. Cristea, C. Cimpoiu, Food Chem. 2014, 150, 113-118. https://doi.org/10.1016/j.foodchem.2013.10.153

24. L. M. Magalhaes, M. Ines, G. S. Almedia, L. Barreiros, S. Reis, M. A. Segundo, Food Anal. Meth. 2012, 5, 530-539. https://doi.org/10.1007/s12161-011-9278-1

25. J. F. Harbertson, R. E. Hodgins, L. N. Thurston, L. J. Schaffer, M. S. Reid, J. L. Landon, C. F. Ross, D. O. Adams, Am J Enol Vitic. 2008, 59, 210-214.

26. E. Buyuktuncel, E. Porgah, C. Colak, Food and Nut. Sci. 2014, 5, 1660-1667. https://doi.org/10.4236/fns.2014.517179

27. Projekt »Modra frankinja - žametno vino Posavja« http:// www.modra-frankinja.com/upload/urejevalnik/datoteke/ 2014_11_27_Strategija-trzenja-vina-modra-frankinja_ FINAL.pdf 


\section{Povzetek}

Vsebnost skupnih fenolov (TPC), flavonoidov (TFC) in taninov (TTC), kakor tudi skupni $\mathrm{SO}_{2}$, skupne kisline, $\mathrm{pH}$, reducirajoči sladkorji so bili določeni v petindvajsetih slovenskih rdečih vinih iz treh ključnih vinorodnih območij: Podravja, Posavja in Primorske. Rezultati so bili kemometrično ovrednoteni, vina pa razvrščena glede na vinorodno območje in sorto vinske trte. Metoda glavnih osi je pokazala, da so vsebnosti TPC, TFC in TTC v prvi vrsti odgovorne za razliko med vini. $Z$ rezultati linearne diskriminantne analize (LDA) pa smo ugotovili, da so analizirani parametri odvisni tako od sorte vinske trte kot tudi od vinorodnega območja. 